Universidad de Lima

Facultad de Derecho

Carrera de Derecho

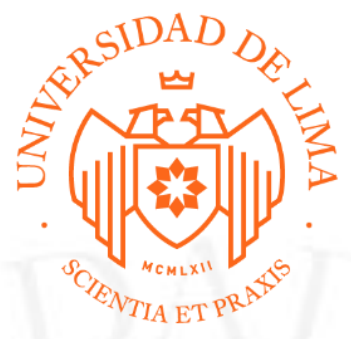

\title{
EXPEDIENTE ARBITRAJE NO.608-2010 \\ SOBRE: NULIDAD DE LAUDO ARBITRAL \\ EXPEDIENTE PENAL NO.1856-2010 SOBRE: \\ ROBO AGRAVADO
}

Trabajo de suficiencia profesional para optar el Título Profesional de Abogado

Marialexandra Perata Rivas Plata

Código 20110958

Lima - Perú

Febrero de 2020 
EXPEDIENTE ARBITRAJE NO.608-2010 SOBRE: NULIDAD DE LAUDO

\title{
ARBITRAL
}

Materia: Nulidad de Laudo Arbitral

$\mathrm{N}^{\mathrm{o}}$ de Expediente: 608-2010

\section{RESUMEN}

El Ministerio Público de Lima interpuso denuncia penal por la presunta comisión del delito de tráfico ilícito de drogas y robo agravado en grado de tentativa. Producto de dicha denuncia se instauró proceso penal y la Segunda Sala Penal con Reos en Cárcel de Lima condenó al procesado a una pena privativa de libertad efectiva de veinte años y el pago de S/. 1000.00 Soles por concepto de reparación civil.

Posteriormente, la Sala Penal Transitoria de la Corte Suprema de Justicia dispuso absolver al sentenciado y, en consecuencia, reformuló la pena imponiéndole quince años de pena privativa de libertad efectiva.

\section{EXPEDIENTE PENAL NO.1856-2010 SOBRE: ROBO AGRAVADO}

\author{
Materia: Robo Agravado \\ $\mathrm{N}^{\mathrm{o}}$ de Expediente: $1856-2010$
}

\section{RESUMEN}

El Ministerio Público de Lima interpuso denuncia penal por la presunta comisión del delito de tráfico ilícito de drogas y robo agravado en grado de tentativa. Producto de dicha denuncia se instauró proceso penal y la Segunda Sala Penal con Reos en Cárcel de Lima condenó al procesado a una pena privativa de libertad efectiva de veinte años y el pago de S/. 1000.00 Soles por concepto de reparación civil.

Posteriormente, la Sala Penal Transitoria de la Corte Suprema de Justicia dispuso absolver al sentenciado y, en consecuencia, reformuló la pena imponiéndole quince años de pena privativa de libertad efectiva. 